\title{
Chrysobrycon eliasi, new species of stevardiine fish (Characiformes: Characidae) from the río Madre de Dios and upper río Manuripe basins, Peru
}

\author{
James Anyelo Vanegas-Ríos ${ }^{1}$, María de las Mercedes Azpelicueta ${ }^{1}$ and Hernán Ortega ${ }^{2}$
}

Chrysobrycon eliasi is described from several drainages of río Madre de Dios and upper río Manuripe basins, río Madeira basin, Peru. The new species is distinguished from its congeners by the maxillary teeth, which are tricuspidate, bicuspidate and conical, and the terminal lateral-line tube developed between caudal-fin rays 10-11. Other characters that help to recognize C. eliasi are the possession of maxilla with 6-15 (usually 11) teeth occupying more than $70 \%$ of the length of the maxilla in adults, predorsal scales 18-22, dorsal-fin to hypural complex length 36.32-41.17\% of standard length (SL), gill-gland length in males 3.57-5.05\% SL, maxillary length 33.76-38.75\% of head length, and branched anal-fin rays 24-30. The discovery of $C$. eliasi allows us to extend the geographic distribution of the genus to the southeast, into the río Madeira basin.

Chrysobrycon eliasi se describe para varios drenajes en las cuencas de los ríos Madre de Díos y Alto Manuripe, cuenca del río Madeira, Peru. La nueva especie puede diferenciarse de sus congéneres por la presencia de dientes maxilares, que son tricuspidados, bicuspidados y cónicos, y el tubo terminal de la línea lateral desarrollado entre los radios caudales 10-11. Otros caracteres que ayudan a reconocer $C$. eliasi son la presencia de 6-15 (usualmente11) dientes maxilares ocupando más del 70\% de la longitud de la maxila en adultos, escamas predorsales 18-22, longitud origen aleta dorsal-hipurales $36,32-41,17 \%$ de longitud estandard (LE), longitud de la glándula branquial en machos 3,57-5,05\% LE, longitud de la maxila 33,76-38,75\% de longitud de la cabeza, y radios ramificados en la aleta anal 24-30. El hallazgo de C. eliasi nos permite ampliar la distribución geográfica del género hacia el sureste en la cuenca del río Madeira.

Key words: Madeira basin, Pouch scale, Sexual dimorphism, Tambopata, Xenurobryconini.

\section{Introduction}

The genus Chrysobrycon Weitzman \& Menezes is a small group of characid fishes, measuring up to $82 \mathrm{~mm} \mathrm{SL}$, distributed in lower altitude freshwater ecosystems between 200 and 375 m a.s.l. in the upper Amazon basin in Ecuador and Peru (Böhlke, 1958; Weitzman \& Thomerson, 1970). The genus Chrysobrycon has two species, C. hesperus (Böhlke, 1958) distributed in the río Napo basin in Ecuador, and C. myersi (Weitzman \& Thomerson, 1970) recorded from río Pachitea in Peru (Böhlke, 1958; Weitzman \& Thomerson, 1970; Weitzman, 2003).

The genus has been considered a basal member of the monophyletic tribe Xenurobryconini (Weitzman \& Menezes, 1998; Castro et al., 2003; Weitzman et al., 2005; Menezes \& Weitzman, 2009; Mirande, 2009, 2010), defined by the presence of a single large pouch scale, with or without hypertrophied radii in males, a synapormophy reported by Weitzman \& Menezes (1998). The same authors diagnosed the males of Chrysobrycon by the presence of a pouch scale, relatively small, somewhat elongate, curved and horizontally folded so that its lateral face forms a laterally concave, broadly open pocket; that pouch scale is confined to the dorsal region of the pouch opening; an additional curved scale is situated close to, and nearly completely against, the medially placed surface of the pouch scale, while this medially placed scale sometimes has its ventral border laterally curved around the ventral border of the pouch scale. Furthermore, the two Chrysobrycon species are characterized by the presence of gill gland (Bushmann et al., 2002), insemination habit, and spermatozoa with elongated nuclei (Burns et al., 1995).

\footnotetext{
${ }^{1}$ Facultad de Ciencias Naturales y Museo, Consejo Nacional de Investigaciones Científicas y Técnicas (CONICET), División Zoología de Vertebrados, Paseo del Bosque S/N B1900FWA, La Plata, Buenos Aires, Argentina. anyelovr@fcnym.unlp.edu.ar (JAVR), azpelicueta@gmail.com.ar (MMA)

${ }^{2}$ Universidad Nacional Mayor de San Marcos, Departamento de Ictiología, Museo de Historia Natural, PO Box 14-0434 Lima - 14, Peru. hortega.musm@gmail.com(HO)
} 
Currently, the phylogenetic relationships and the geographic distribution of the Chrysobrycon species are unknown and poorly understood. One of the authors (JAVR.), examined several lots from the Museo de Historia Natural (Universidad Nacional Mayor de San Marcos, Peru) and the Royal Ontario Museum (Canada), and found several samples identified as Gephyrocharax Eigenmann that actually belong to Chrysobrycon. Further comparisons among Chrysobrycon species confirmed that these specimens constitute a new species herein described; in addition, a key to Chrysobrycon species is provided.

\section{Material and Methods}

Measurements and counts are according to Fink \& Weitzman (1974) and Menezes \& Weitzman (2009), with the addition of the following measurements: dorsal-fin to pectoralfin length, dorsal-fin to adipose-fin length, pectoral-fin to pelvic-fin length, pelvic-fin to anal-fin length (all of them taken from origin to origin), maxillary length (most anterior visible point to posterior margin), and postorbital length. The gillgland length in males was measured from the most anterior to most posterior portions. Measurements were taken point to point with Mitutoyo digital caliper at $0.01 \mathrm{~mm}$ under stereomicroscope and are expressed as percentages of standard length (SL) or head length (HL).

In counts, the range is given first, the mode in parentheses, and the holotype counts marked by an asterisk, followed by the number of specimens counted. The scale on the median dorsal row or the small scale just below to dorsal-fin rays insertion is excluded from the count of longitudinal scale rows between the dorsal fin and lateral line. Specimens were cleared and counterstained (C\&S) following Taylor \& van Dyke (1985). Total vertebral count includes the four vertebrae of Weberian apparatus; preural centrum 1 plus ural centrum 1 (PU1+U1) were counted as one vertebral element. A key for identification of Chrysobrycon species is given based on the examined material; data from Weitzman \& Thomerson (1970) was included only in the ranges of counts.

The statistical analyses were performed using PAST 2.07 (Hammer et al., 2001) and SigmaPlot 10.0 for Windows (2006, Systat Software, Inc.) for morphometrics and meristics variables. Tukey box plots were used to describe the variance of counts that showed differences among species and that were considered relevant to diagnose the new species and in the key. Morphometric data was log-transformed (base-10 $\log$ ) before any subsequent statistical step mentioned herein. Hypothesis of statistical significance of $t$-test and $F$-test were of two-tailed, accomplished to compare means and variances among morphometrics variables by sexes into new species ( $p$ $\leq 0.05$ ). Test without statistical significance are not presented herein. Principal component analysis (PCA) of morphometric data was used to compare the variation between sexes of new species and among species of Chrysobrycon. Morphometric variables were processed using the covariance matrix. Given that the first component (PC1) is known to be associated to size (Marcus, 1988), the second and third principal component (PC2 and PC3, respectively) were used to analyze the differences in shape. Regression plots by sex were evaluated for each variable measured, but only the plots where the following two conditions are found, are presented herein: 1) evidence for a low overlapping in data, and 2) variables strongly affecting the PC2.

The material examined is deposited in the collections of AI, ANSP, CAS, LACM, and MUSM; acronyms are according to Eschmeyer (1998), except AI, Asociación Ictiológica, La Plata, Argentina.

\section{Results}

\section{Chrysobrycon eliasi, new species Figs. 1-4}

Holotype. MUSM 39970, $34.25 \mathrm{~mm}$ SL, male, Peru, Madre de Dios, Tambopata, río Madre de Dios basin, Creek Loboyoc, $12^{\circ} 27^{\prime} 7.27^{\prime \prime S} 69^{\circ} 7^{\prime} 42.53^{\prime \prime} W, 210 \mathrm{~m}$ a.s.1., 7 Jul 2004, M. Hidalgo, S. Martínez \& V. Chipollini.

Paratypes. All from Peru. AI 287, 3, 32.95-43.50 mm SL (2 C\&S), Madre de Dios, Tambopata, río Manuripe basin, Creek km 50, $12^{\circ} 11^{\prime} 21.24$ ”S 696'57.36”W, 248 m a.s.l., 8 Jul 2004, M. Hidalgo, S. Martínez \& V. Chipollini. AI 288, 2, 37.27-37.63 mm SL, Madre de Dios, Tambopata, río Manuripe basin, Creek Yarinal, 12³'6.12"S $69^{\circ} 4^{\prime} 49.77^{\prime \prime}$, 250 m a.s.1., 9 Jul 2004, M. Hidalgo, S. Martínez \& V. Chipollini. MUSM 39971, 14, 26.14-40.81 mm SL (11, 30.13-40.81 $\mathrm{mm} \mathrm{SL}$ ), collected with the holotype. MUSM 39972, 8, 28.01-43.15 mm SL (6, 28.01-30.70 mm SL), Madre de Dios, Tambopata, río Manuripe basin, Creek km 50, 12 11 '21.24”S 696'57.36”W, 248 m a.s.l., 8 Jul 2004, M. Hidalgo, S. Martínez \& V. Chipollini. MUSM 39973, 2, 36.11-37.63 mm SL, Madre de Dios, Tambopata, río Madre de Dios basin, Creek Loboyoc, 12 27'21.17'S 6907'41.67”W, $225 \mathrm{~m}$ a.s.l., 23 Aug 2004, H. Ortega, B. Rengifo \& L. Figueroa. MUSM 39974, 3, 29.33-41.22 mm SL, Madre de Dios, Tambopata, San Antonio, río Heath basin, Creek San Antonio, 12 $41^{\circ} 03.14^{\prime \prime} \mathrm{S}$ 6843'8.86”W, 193 m a.s.l., 28 May 1992, H. Ortega.

Non-type specimens. ROM 66378,4 of 5, 27.58-31.63 mm SL, Peru, Madre de Dios, Tambopata, La Colpa, lodge, río Tambopata, stream at left bank at $2.1 \mathrm{~km}$.

Diagnosis. Chrysobrycon eliasi is distinguished from its congeners by the maxillary teeth, tricuspidates, bicuspidates, and conical (Fig. 3), vs. all maxillary teeth tricuspidate to pentacuspidate in C. myersi and C. hesperus. Chrysobrycon eliasi also has the terminal lateral-line tube developed between caudal-fin rays 10-11 vs. absence of the terminal lateral-line tube in C. myersi and C. hesperus. Furthermore, Chrysobrycon eliasi differs from $C$. hesperus by the presence of 6-15 (mode $=11 ; \mathrm{n}=28$ ) maxillary teeth (Fig. $5 \mathrm{~b}$ ) occupying more than $70 \%$ of the length of the maxilla in adults, $v s$. maxilla with 2-9 teeth (mode $=3 ; n=11$ ) occupying less than $70 \%$ of its length in adults, and a lower number of predorsal scales (Fig. 5 d $) 18-22($ mode $=19 ; \mathrm{n}=28) v s .22-23(\operatorname{mode}=22 ; \mathrm{n}=11)$, respectively. Chrysobrycon eliasi is also readily differentiated from C. myersi by a smaller dorsal-fin to hypural complex 


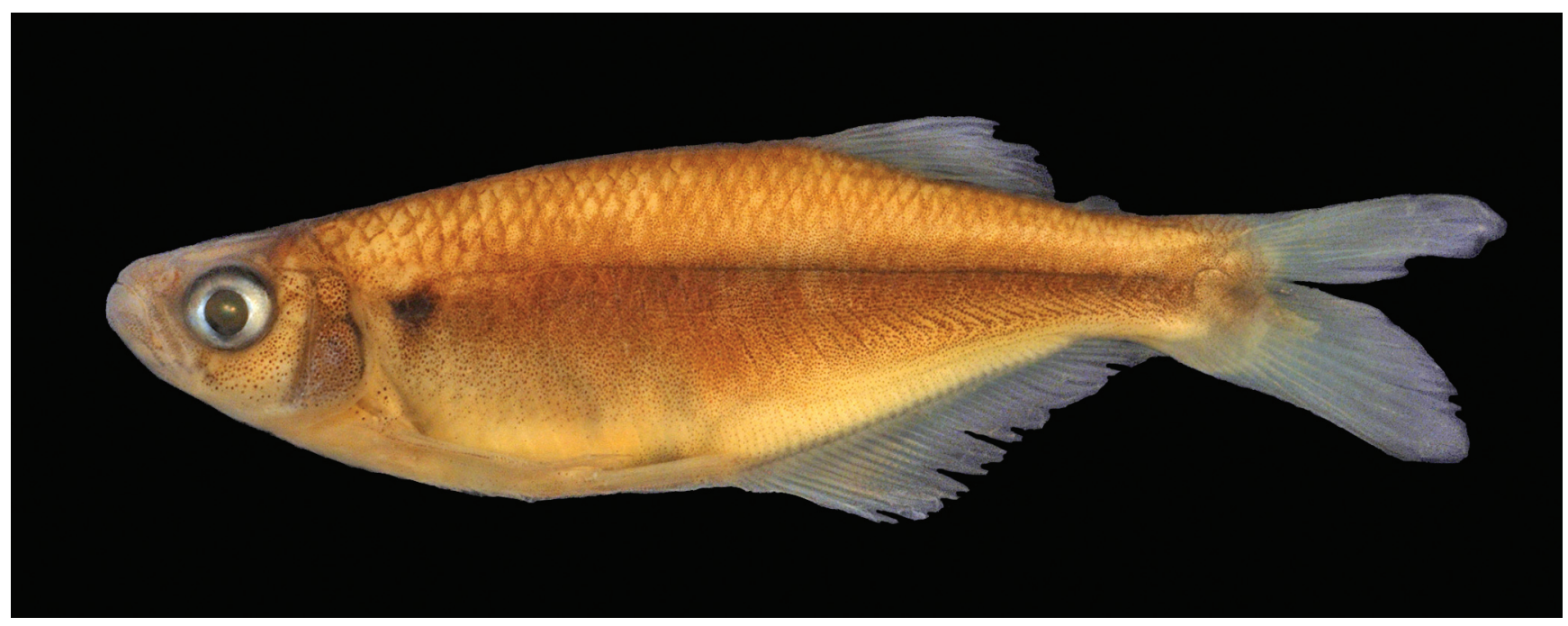

Fig. 1. Chrysobrycon eliasi, holotype, male, MUSM 39970, 34.25 mm SL, Peru, Madre de Dios, Tambopata, río Madre de Dios basin, Creek Loboyoc.

length 36.32-41.17\% SL vs. 42.19-47.38\% SL; smaller gill-gland length in males, $3.57-5.05 \%$ SL vs. $6.52-6.66 \%$ SL; shorter maxillary length, $33.76-38.75 \%$ HL vs. $39.85-48.28 \% \mathrm{HL}$; and a lower number of branched anal-fin rays (Fig. 5a), 24-30 vs. 3336. Chrysobrycon eliasi has a different pattern of scales near to the pouch scale of males; the additional small scale is set under the pouch scale and its ventral border is not seen in the lateral view.

Description. Morphometric data for holotype (Fig. 1) and 27 paratypes in Table 1. Largest male $39.90 \mathrm{~mm} \mathrm{SL}$, largest female $43.50 \mathrm{~mm} \mathrm{SL}$.

Body laterally compressed, with maximum depth at vertical through half length of pelvic fin. Dorsal profile of body straight over head and convex from supraoccipital region to dorsalfin origin, slanting ventrally and slightly concave or smooth from last dorsal-fin ray to caudal peduncle. Dorsal profile of caudal peduncle straight. Ventral profile of body convex from tip of snout to pelvic-fin origin, slanting dorsally and straight from this point to caudal peduncle. Ventral profile of caudal peduncle straight. Dorsal-fin origin located at vertical through anal-fin rays 8 and 10 . Adipose fin located at vertical through last anal-fin ray. Anal-fin origin situated in posterior half of body, always slightly anterior to dorsal-fin origin. Pelvic-fin origin slightly anterior to half length of body. Pectoral fin relatively long, its posterior tip reaching half length or about three quarters of pelvic-fin length (Fig. 2).

Head with anterior portion acute. Frontal fontanel absent. Epiphyseal branch of supraorbital canal absent. Nostrils somewhat rounded separated by one skin fold, posterior opening larger. Mouth superior, lower jaw projecting slightly anterior to upper jaw. Maxilla relatively short, not reaching posteriorly vertical through anterior border of pupil.

Dorsal fin ii-iii,7-9 (ii, $\left.8^{*}\right), \mathrm{n}=28$. Eight or nine proximal pterygiophores in dorsal fin. Anal fin iv-v,24-30 (v,28*), $\mathrm{n}=28$.
Twenty eight to 30 proximal pterygiophores in anal fin. Pectoral fin i, $9^{*}-10(\mathrm{i}, 10), \mathrm{n}=28$. Pelvic fin i,5-7,i $\left(\mathrm{i}, 6, \mathrm{i}^{*}\right), \mathrm{n}=28$; one specimen with $\mathrm{i}, 7$. Caudal fin forked with $10 / 9$ principal rays in all specimens, $n=25$. One terminal lateral-line tube present between membranes of caudal-fin rays 10-11, $\mathrm{n}=2$.

Premaxilla with two rows of teeth. Outer row teeth often tricuspidate and rarely bicuspidate, not aligned, with 4-6 (5*), $\mathrm{n}=28$. Inner row with teeth pentacuspidate and sometimes tetracuspidate, with $4-5^{*}(4), n=28$. Maxilla bearing teeth in more than $70 \%$ of its length in adults. Maxillary teeth 6-15 (11) $, 12^{*}, n=28$. First one to eight teeth of maxilla tricuspidate or bicuspidate, remaining teeth conical. Dentary with three anterior teeth large and pentacuspidate; one median sized usually tetracuspidate; posterior ones conical and smaller 12-19 (16), 18*, $\mathrm{n}=23$ (Fig. 3).

Scales cycloid, with several radii along posterior field. Lateral line complete, perforated scales $42 *-46$ (43), $n=28$. Predorsal scales 18-22 (19), 20*, $\mathrm{n}=28$. Scale rows between dorsal fin and lateral line 6-7 $\left(7^{*}\right), \mathrm{n}=28$. Scale rows between lateral line and anal fin 4-6 $\left(5^{*}\right), \mathrm{n}=28$. Scale rows between lateral line and pelvic fin 4-6 (5*), $\mathrm{n}=28$. Scale rows around caudal peduncle $15-16^{*}(15), \mathrm{n}=28$. One row of scales forming sheath along anal-fin base, with 14-26 (18*) scales, $\mathrm{n}=26$. Sometimes, several scales located in one row between body scales and sheath.

Total number of vertebrae $42, n=2$. Gill-rakers on dorsal limb of first arch 5-6 (6*), $\mathrm{n}=9$; ventral limb with 11-12 (12*), $\mathrm{n}=9$. Branchiostegal rays distributed as follows: three on anterior ceratohyal and one on posterior ceratohyal, $\mathrm{n}=2$.

Color in alcohol. Ground color pale yellowish in preserved males and females, dorsally darker and slightly lighter ventrally. Scattered chromatophores over all body, dark brown and black, more concentrated dorsally, sometimes forming reticulate pattern. Dark black lateral band extended from 


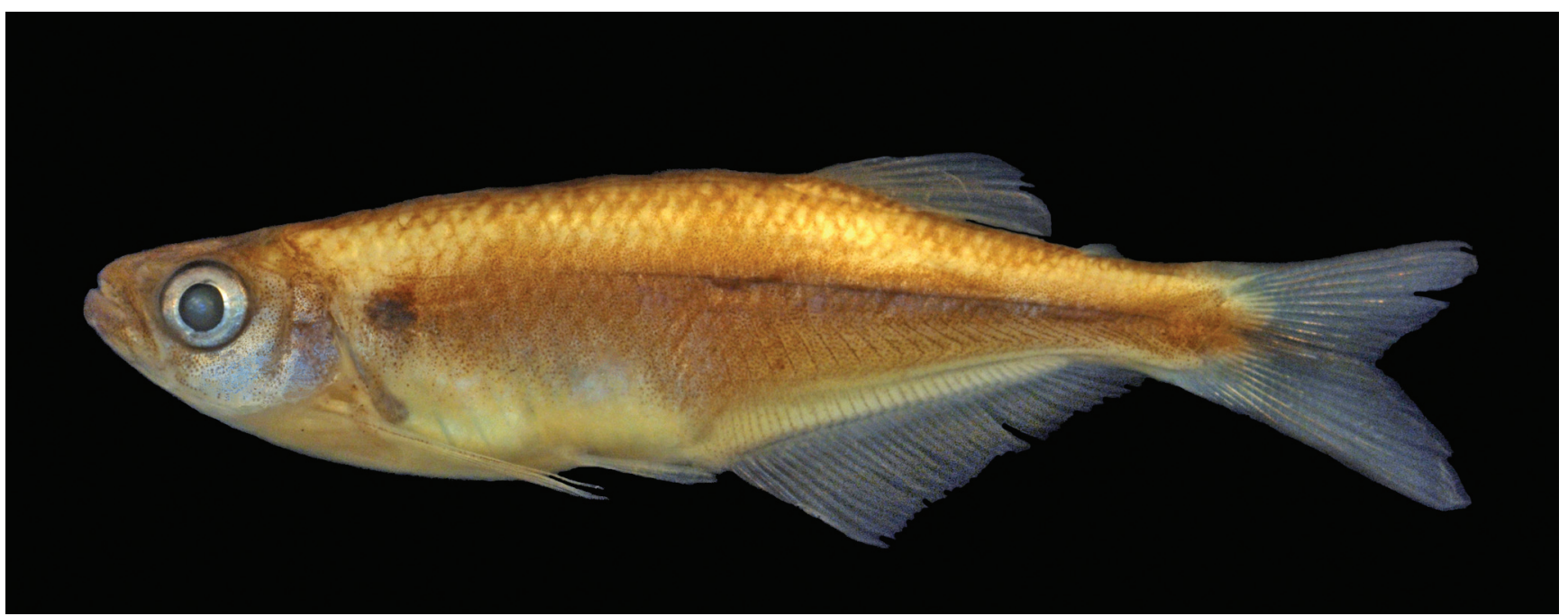

Fig. 2. Chrysobrycon eliasi, female, paratype, MUSM 39973, 37.63 mm SL, Peru, Madre de Dios, río Madre de Dios basin, Creek Loboyoc.

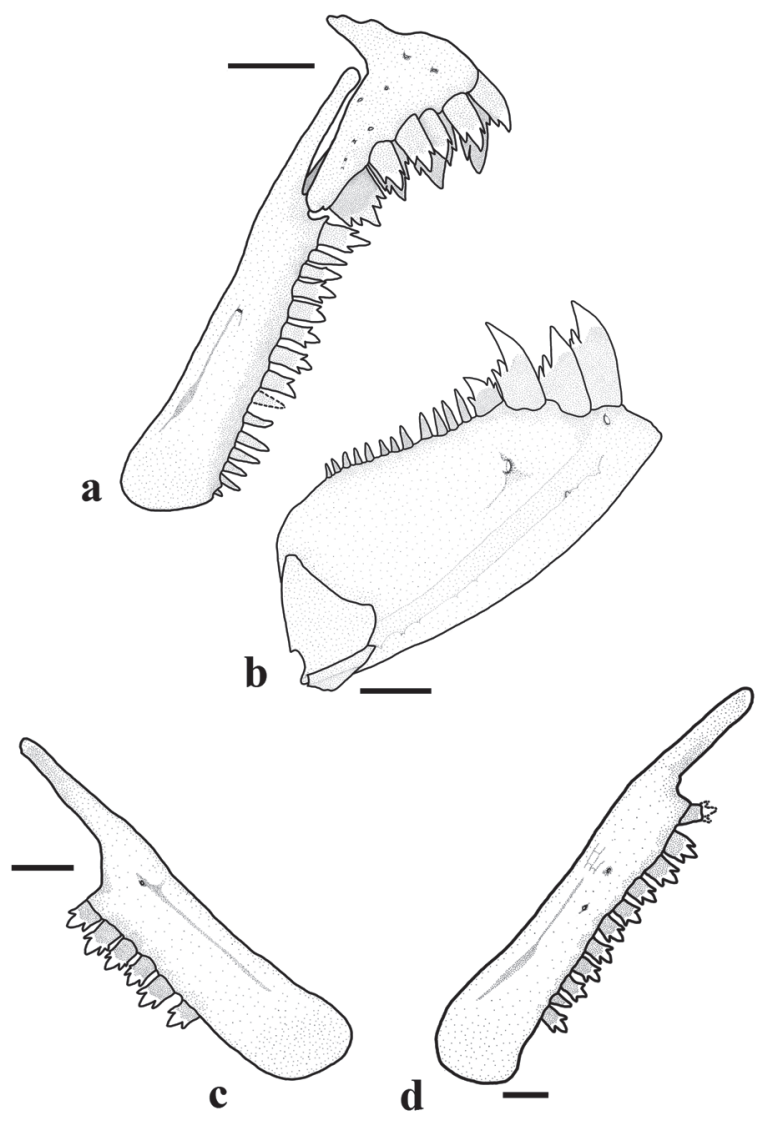

Fig. 3. Chrysobrycon eliasi, AI 287, paratype, female 32.95 mm SL. Lateral view of jaw and dentition: (a) Upper jaw, right side. (b) Lower jaw, right side. Lateral view of maxilla: (c) $C$. hesperus, maxilla, left side, male, MUSM 28665. (d) C. myersi, maxilla, right side, male, MUSM 38671. Scale bar $=1 \mathrm{~mm}$. posterior region of humeral spot to middle caudal peduncle. Black chromatophores forming two very narrow lines, one along mid-dorsal line and other one crossing mid-flank slightly above lateral-line scales, from about vertical through pelvicfin origin to middle caudal peduncle. Black chromatophores forming stripes over myomeres. Humeral spot somewhat rounded, several specimens with scattered black chromatophores forming spot more ventrally elongated. Caudal peduncle region with scattered black and dark brown chromatophores, infrequently forming blotch. Dorsal and anal fins hyaline with scattered black chromatophores more heavily concentrated along membranes of rays. Pectoral and pelvic fins hyaline with scattered black chromatophores, mainly placed on membranes of rays. Anterior membranes of anal-fin rays with black chromatophores heavily concentrated. Caudal fin hyaline with scattered black chromatophores along

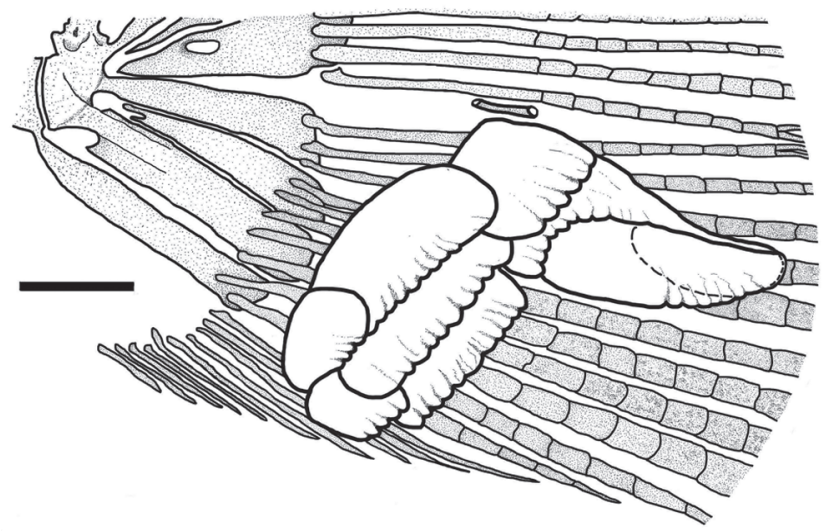

Fig. 4. Chrysobrycon eliasi, male, AI 287, 39.9 mm SL. Lateral view of the caudal fin, left side. Note the squamation associated to pouch scale in the ventral lobe. Scale bar $=1 \mathrm{~mm}$. 

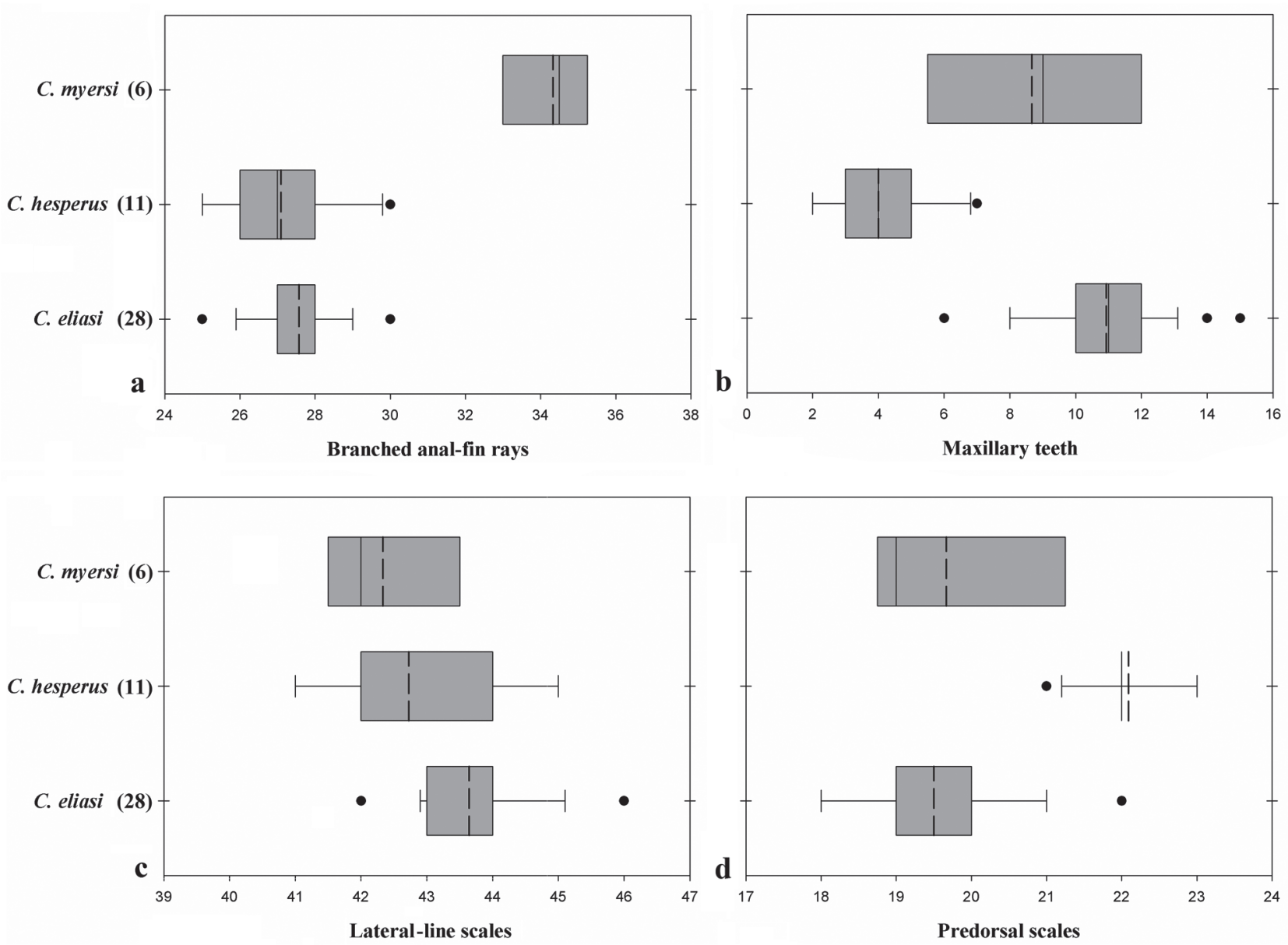

Fig. 5. Comparative Tukey box plots showing the variation of (a) number of branched rays of anal fin, (b) number of teeth in maxilla, (c) number of lateral-line scales, and (d) predorsal scales of Chrysobrycon eliasi, C. hesperus, and C. myersi. Number of specimens between parentheses.

membranes and also on rays 1 and 19. Adipose fin hyaline sometimes with black chromatophores in its base.

Head dark brown dorsally and more yellowish ventrally. Chromatophores dark brown scattered on opercle and infraorbitals. Infraorbitals pale yellowish and sometimes slightly silver. Iris silvery. Maxilla with few chromatophores. Snout heavily covered by black chromatophores.

Sexual dimorphism. The males of Chrysobrycon eliasi are differentiated from females by the presence of bony hooks on rays of the caudal, pelvic, and anal fins. Caudal fin bears 621 tiny hooks, anterodorsally oriented on the posterior half of rays 13-17. All rays of pelvic fin bear short, slender hooks, anterolaterally placed almost all over the entire length of the rays; usually two pairs per segment, and more numerous on medial rays. Anal fin has 5-11 husky hooks; one pair per segment, anterodorsally placed on the last unbranched ray and branched rays 1-11; the number of hooks increases in middle rays. The males also differ from females by the presence of modified scales forming a pouch on the lower lobe of caudal fin (Fig. 4). The pattern of scales on the caudal fin includes a pouch scale, somewhat elongate, curved and horizontally folded with its lateral face forming a concave open pocket; the dorsal fold of the pouch scale forms the dorsal region of the pouch opening. An additional small and also curved scale is set under the pouch scale; it is shorter than the length of the pouch scale and its ventral border is not seen in the lateral view. The length of the scale is shorter than the length of the pouch scale.

The males have a gill gland, relatively long and anteriorly formed by ventral limb of gill filaments, 10-15 (12), 11*, joined together; the total number of ventral limb gill filaments is 24$28(28), 25^{*}, \mathrm{n}=12$. Among all males examined (27.58-39.90 $\mathrm{mm} \mathrm{SL}$ ), the gill gland and hooks on fin rays were absent in one specimen of $32.6 \mathrm{~mm} \mathrm{SL}$. The length of the gill gland was $3.57-5.05 \% \mathrm{SL}$ (mean $=4.21 \% \mathrm{SL}$ ) SL, $4.11 \% \mathrm{SL} *, \mathrm{n}=9$. Principal component analysis grouped males of Chrysobrycon eliasi separately from females along PC2, except for three males (Figs. 6a-b). The second principal component was strongly affected by caudal peduncle depth $(-0.51)$, pelvic-fin to anal-fin length $(0.47)$, pelvic-fin length $(-0.39)$, caudal peduncle length $(-0.35)$, pectoral-fin to pelvic- 
fin length (0.24) and depth at dorsal-fin origin (-0.16). In addition, two of them, pelvic-fin to anal-fin length $(\mathrm{t}=0.85$, $\mathrm{p}=0.40 ; F=4.32, \mathrm{p}=0.01)$, and caudal peduncle depth $(\mathrm{t}=$ $-2.20, \mathrm{p}=0.04 ; F=1.04, \mathrm{p}=0.95)$ were found to be significantly different to either $t$-test or $F$-test. Regression plots were more informative because of minimal overlapping to characterize males and females in the following variables: depth at dorsal-fin origin, pelvic-fin length, caudal peduncle length and depth, all as function of SL (Figs. 7a-d). Usually at higher values of SL, females and males are strongly dimorphic.

Multivariate analyses. The principal component analysis among species separate Chrysobrycon eliasi from C. hesperus and C. myersi along the PC2 axis (Figs. 6c-d), except for two specimens of $C$. hesperus. The second principal component was more strongly affected by caudal peduncle depth $(-0.46)$, maxillary length (-0.32), pelvic-fin to anal-fin length $(-0.32)$, dorsal-fin base length (-0.33), eye to dorsal-fin length $(0.27)$, pectoral-fin length (0.24), snout to dorsal-fin origin (0.23), dorsal-fin to adipose-fin length (-0.23), and upper jaw length
$(-0.22)$. Some of the previous values were included in the diagnosis of $C$. eliasi and used to differentiate it from both $C$. hesperus and C. myersi; two values are useful to differentiate $C$. hesperus and $C$. myersi: pectoral-fin length (23.97-28.43\% SL vs. $22.48-24.59 \%$ SL) and pelvic-fin to analfin length (14.54-16.92\% SL vs. 12.59-14.25\% SL); dorsal-fin base length was not useful to differentiate the species.

Distribution. The new species is known from different localities of the río Madre de Dios basin and the upper río Manuripe basin, both flowing into the río Madeira basin, Peru (Fig. 8).

Ecological notes. Chrysobrycon eliasi is usually found in dark water creeks at 210-250 m a.s.1., often slightly acid with $\mathrm{pH}$ ranging between 5.8 and 6.2, and characterized by soft substratum, including sand, clay and fallen leaves, surrounded by primary forest.

Etymology. The species is named as patronym in honor and memory to the late Elias Vanegas G., father of the senior author (J.V-R.).
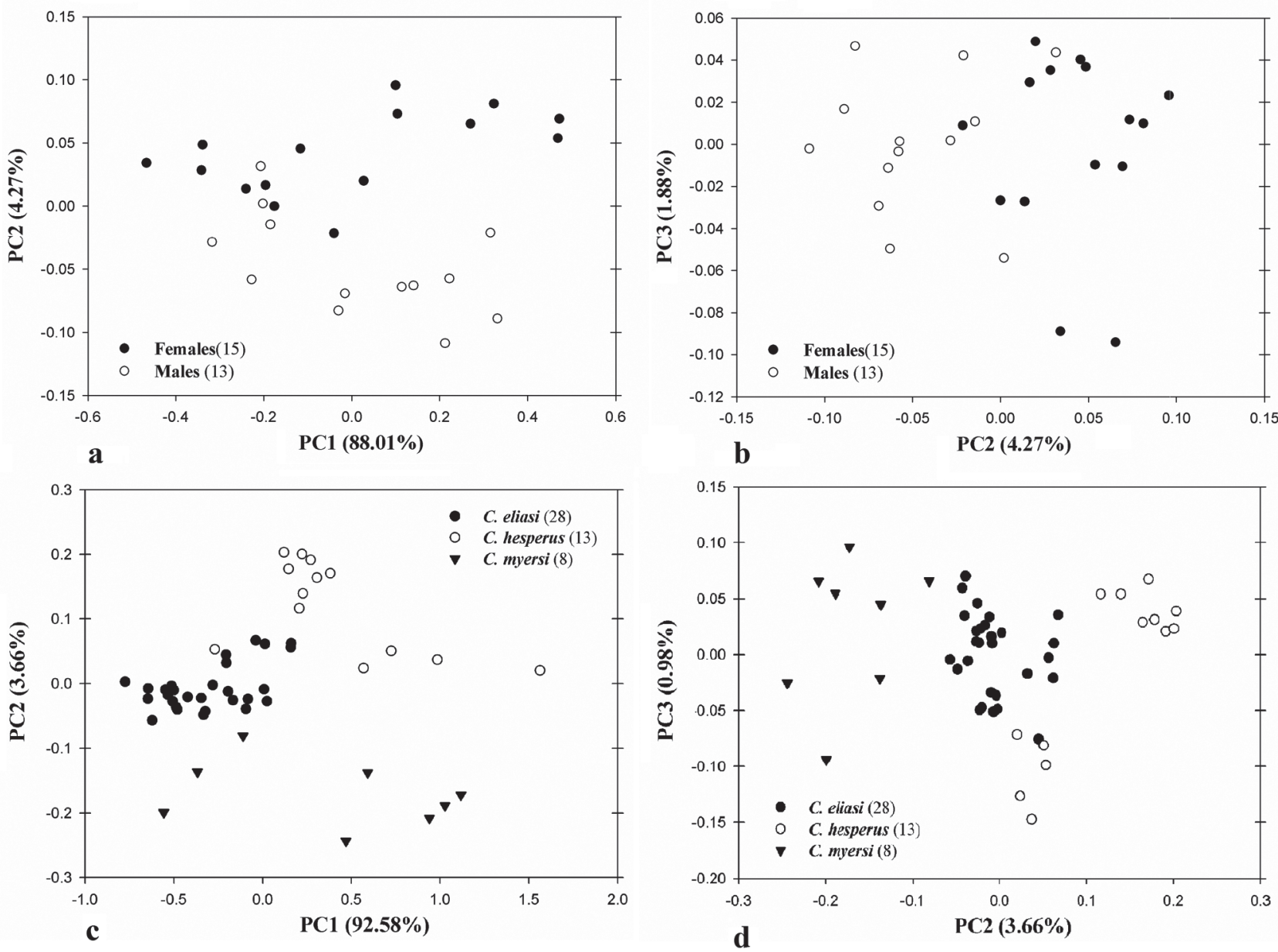

Fig. 6. Principal component analyses of morphometric data by sex of Chrysobrycon eliasi (a-b) and comparing Chrysobrycon species (c-d). PC1, PC2 and PC3 correspond to the first, second and third principal components, respectively. 
Remarks. Specimens of Chrysobrycon eliasi from río Tambopata (ROM 66378) were listed as non-type specimens. We did not find any clear differences between samples from río Tambopata and the type series, but some variation was found in the gill-gland length of males: $5.33-6.40 \% \mathrm{SL}, \mathrm{n}=2$ vs. $3.57-5.05 \% \mathrm{SL}, \mathrm{n}=9$, respectively. Statistical tests are not used herein because of the small number of specimens examined of that population; therefore, we considered them as non-type specimens.

\section{Key to Chrysobrycon species:}

1a. Thirty three to 36 branched anal-fin rays; $18-19$ longitudinal scale rows around caudal peduncle; distance from snout to dorsal-fin origin $56.59-61.91 \% \mathrm{SL}$; distance from dorsalfin to hypural complex $42.19-47.38 \% \mathrm{SL}$

Chrysobrycon myersi

1b. Twenty four to 32 branched anal-fin rays; $14-15$ longitudinal scales rows around caudal peduncle; distance from snout to dorsal-fin origin $61.15-68.47 \%$ SL; distance from dorsalfin to hypural complex $34.32-41.17 \%$ SL

2a. Maxilla with 3-9 teeth (frequently 6) tricuspidate to pentacuspidate, occupying less than $70 \%$ of its length in adults; males with bony hooks restricted more distally on anal-fin rays as one proceed posteriorly along the fin; 2225 predorsal scales Chrysobrycon hesperus 2b. Maxilla with 6-15 teeth (frequently 11) conical, bicuspidate, and tricuspidate, occupying more than $70 \%$ of its length in adults; males without bony hooks on the distal portion of the anal-fin rays; $18-22$ predorsal scales

Chrysobrycon eliasi

\section{Discussion}

Böhlke (1958) and Weitzman \& Thomerson (1970) described two species assigned to the genus Hysteronotus Eigenmann, H. hesperus and H. myersi, respectively. Weitzman $\&$ Menezes (1998) redefined the genus Hysteronotus in a
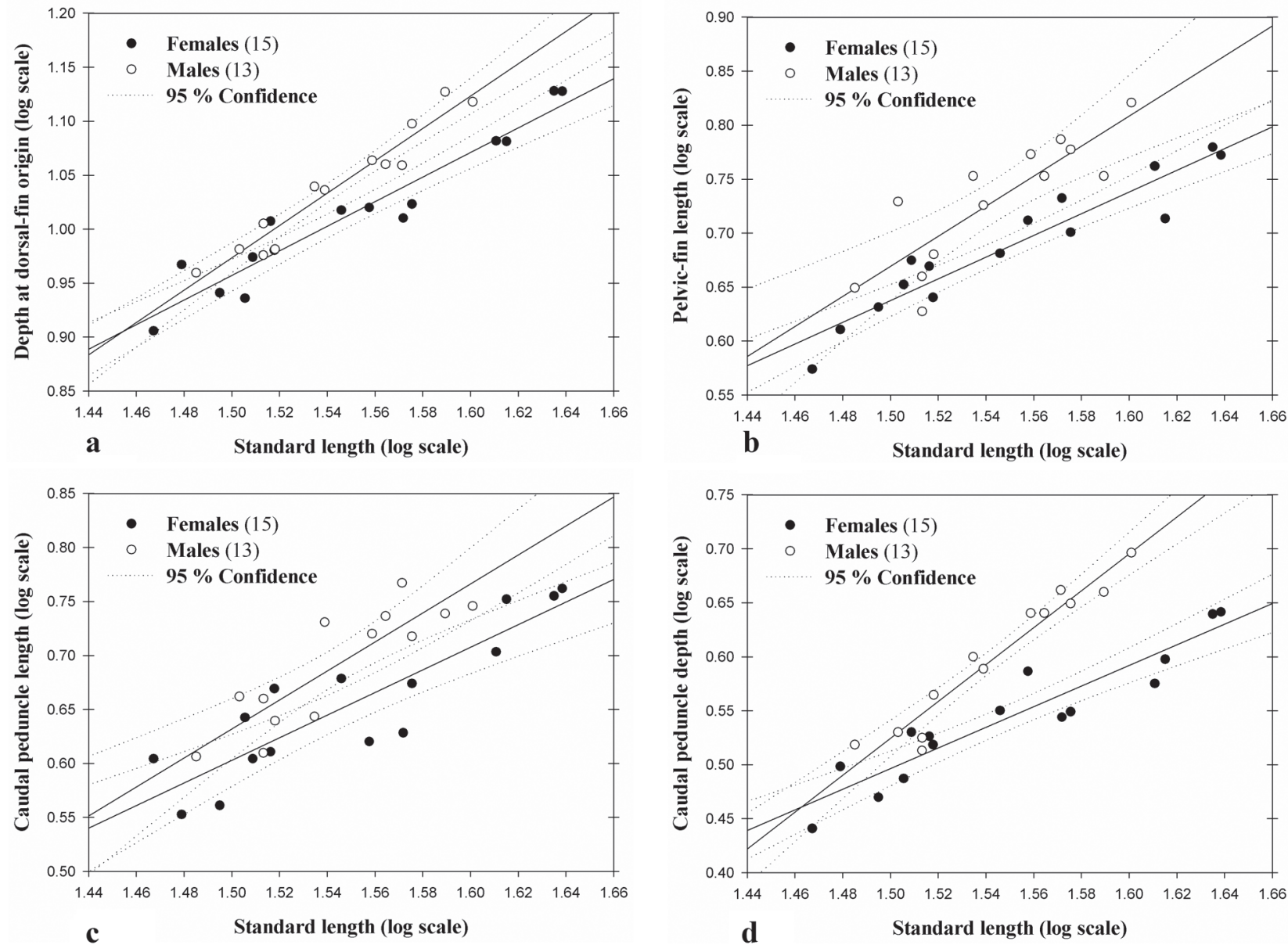

Fig. 7. Comparative regression plots of males and females of Chrysobrycon eliasi. (a) Depth at dorsal-fin origin as function of SL (females: $\mathrm{r}^{2}=0.92$; males: $\mathrm{r}^{2}=0.94$ ), (b) pelvic-fin length as function of SL (females: $\mathrm{r}^{2}=0.90$; males: $\mathrm{r}^{2}=0.72$ ), (c) caudal peduncle length as function of SL (females: $\mathrm{r}^{2}=0.79$; males: $\mathrm{r}^{2}=0.76$ ), (d) caudal peduncle depth as function of SL (females: $\mathrm{r}^{2}$ $=0.87$; males: $\mathrm{r}^{2}=0.93$ ). 


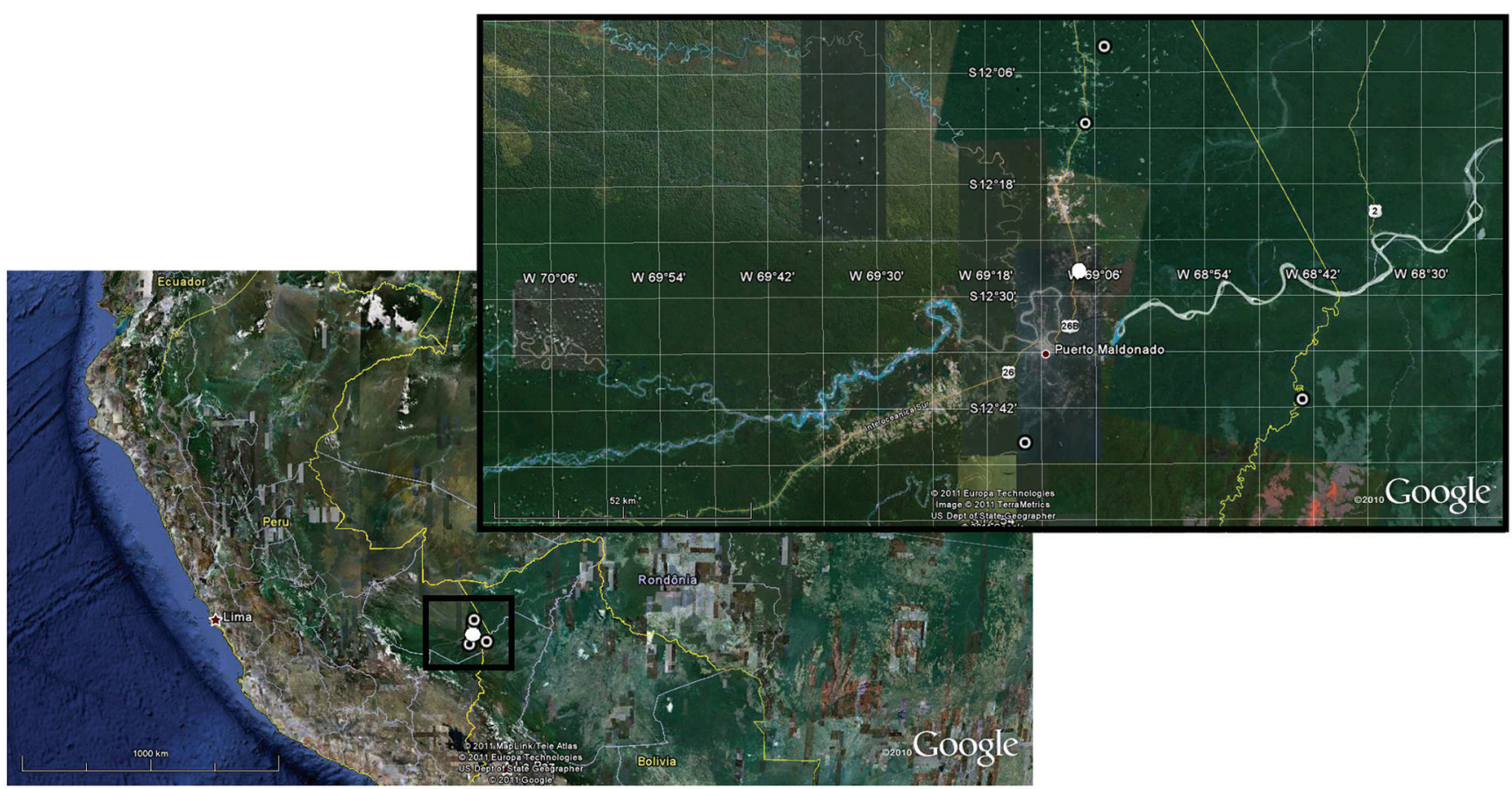

Fig. 8. Geographic distribution of Chrysobrycon eliasi. White circle indicates two localities, including type locality. The inset from upper part of figure is delimited by black line and correspond to a zoom of the rectangle indicate below it.

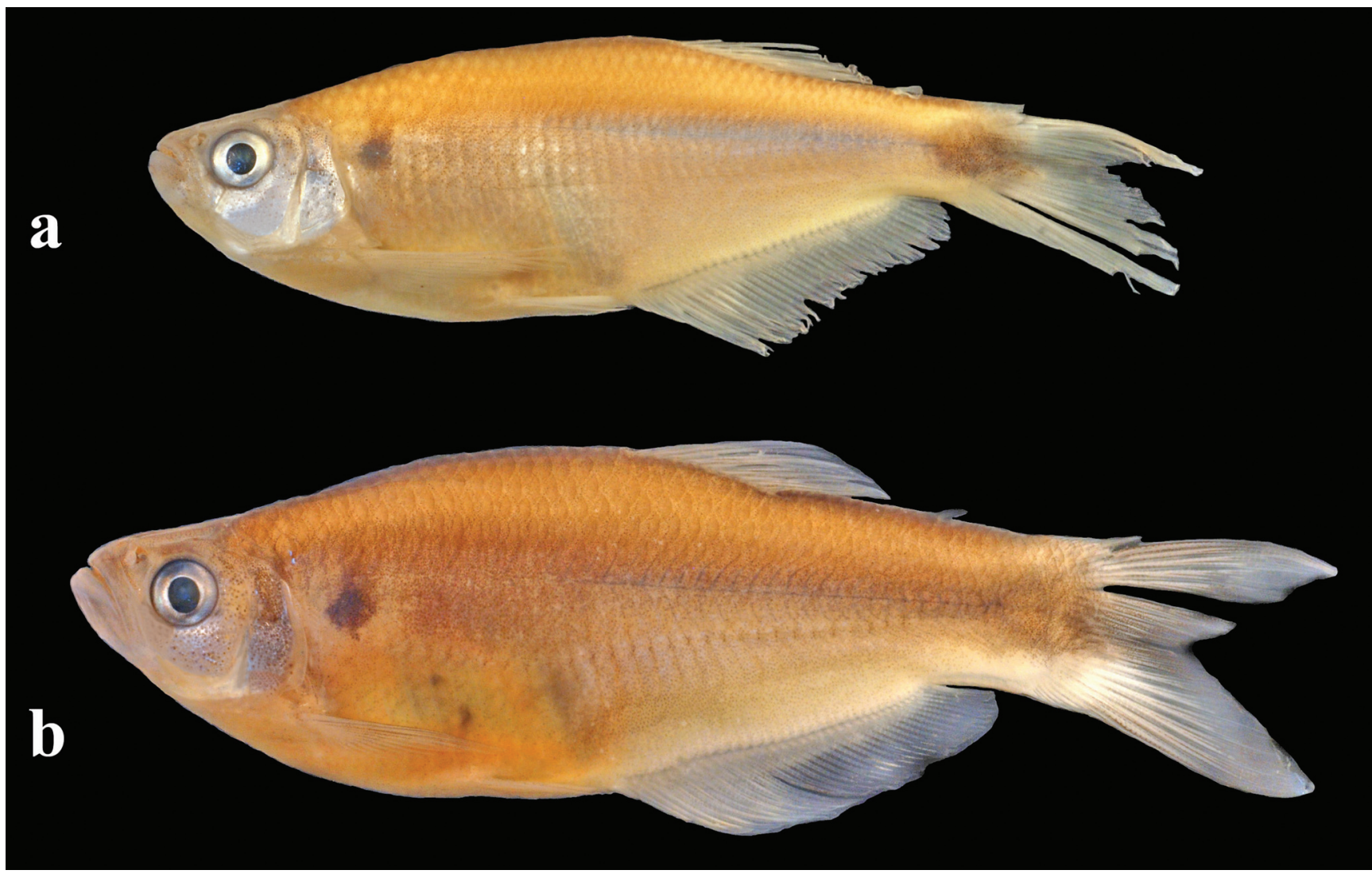

Fig. 9. (a) Chrysobrycon hesperus, MUSM 28665, 50.70 mm SL; (b) C. myersi, MUSM 38671, 60.66 mm SL. 
Table 1. Morphometric data of holotype and 27 paratypes of Chrysobrycon eliasi from río Madre de Dios and Upper río Manuripe basins. $\mathrm{n}=$ number of specimens; $\mathrm{SD}=$ standard deviation. The values of the holotype are included in the range of males.

\begin{tabular}{|c|c|c|c|c|c|c|c|c|c|}
\hline \multirow{2}{*}{ Characters } & \multicolumn{6}{|c|}{ Males } & \multicolumn{3}{|c|}{ Females and juveniles } \\
\hline & Holotype & $\mathrm{n}$ & Range & Mean & SD & $\mathrm{n}$ & Range & Mean & SD \\
\hline \multirow[t]{2}{*}{ Standard length $(\mathrm{mm})$} & 34.25 & 13 & $27.58-39.90$ & 35.08 & - & 15 & $29.33-43.50$ & 35.71 & - \\
\hline & \multicolumn{9}{|c|}{ Percentages of standard length } \\
\hline Depth at dorsal-fin origin & 31.97 & 13 & $29.02-34.49$ & 31.31 & 1.63 & 15 & 26.94-31.12 & 29.14 & 1.38 \\
\hline Snout to dorsal-fin origin & 64.50 & 13 & $62.56-64.89$ & 63.55 & 0.83 & 15 & $61.15-65.86$ & 63.70 & 1.25 \\
\hline Snout to pectoral-fin origin & 28.82 & 13 & $27.21-29.43$ & 28.20 & 0.76 & 15 & $26.71-28.17$ & 27.41 & 0.41 \\
\hline Snout to pelvic-fin origin & 46.19 & 13 & $44.48-49.52$ & 46.05 & 1.32 & 15 & $43.81-48.16$ & 45.77 & 1.13 \\
\hline Snout to anal-fin origin & 57.64 & 13 & $56.81-61.26$ & 58.54 & 1.20 & 15 & $57.11-60.76$ & 58.64 & 1.03 \\
\hline Dorsal-fin to pectoral-fin length & 46.80 & 13 & $44.27-50.17$ & 46.76 & 1.39 & 15 & $44.27-47.88$ & 46.15 & 1.03 \\
\hline Dorsal-fin to adipose-fin length & 25.28 & 13 & $24.59-26.31$ & 25.42 & 0.60 & 15 & 23.93-26.04 & 25.29 & 0.59 \\
\hline Dorsal-fin to hypurals complex length & 37.93 & 13 & $36.32-41.17$ & 38.71 & 1.46 & 15 & $36.62-40.12$ & 38.08 & 1.07 \\
\hline Eye to dorsal-fin origin & 50.98 & 13 & 49.74-52.15 & 50.98 & 0.75 & 15 & 48.07-52.94 & 51.24 & 1.44 \\
\hline Pectoral-fin to pelvic-fin length & 17.87 & 13 & $15.76-22.63$ & 18.70 & 1.32 & 15 & $16.13-20.74$ & 19.31 & 1.25 \\
\hline Pelvic-fin to anal-fin length & 12.85 & 13 & $12.85-15.86$ & 14.10 & 0.94 & 15 & $12.12-16.67$ & 14.74 & 1.21 \\
\hline Dorsal-fin length & 17.58 & 13 & $16.26-21.65$ & 19.20 & 1.44 & 15 & $17.75-20.67$ & 19.32 & 0.92 \\
\hline Dorsal-fin base length & 11.59 & 13 & $10.77-11.85$ & 11.33 & 0.36 & 15 & $10.31-12.01$ & 11.00 & 0.42 \\
\hline Pectoral-fin length & 26.01 & 13 & $22.69-26.40$ & 24.80 & 1.24 & 15 & $23.31-26.47$ & 24.67 & 0.74 \\
\hline Pelvic-fin length & 16.53 & 13 & $13.00-16.82$ & 15.40 & 1.18 & 15 & $12.54-14.66$ & 13.75 & 0.60 \\
\hline Anal-fin length & 18.36 & 13 & $15.67-20.34$ & 17.81 & 1.04 & 15 & $16.69-20.05$ & 18.14 & 0.94 \\
\hline Anal-fin base length & 33.66 & 13 & $31.48-35.73$ & 33.07 & 1.18 & 15 & $30.23-34.30$ & 32.74 & 1.05 \\
\hline Caudal peduncle depth & 11.62 & 13 & $10.00-12.46$ & 11.39 & 0.78 & 15 & $9.21-10.69$ & 9.88 & 0.47 \\
\hline Caudal peduncle length & 12.85 & 13 & $12.48-15.70$ & 14.06 & 0.97 & 15 & $11.39-14.19$ & 12.77 & 0.91 \\
\hline \multirow[t]{2}{*}{ Bony head length } & 25.61 & 13 & $24.36-25.95$ & 25.14 & 0.53 & 15 & $22.90-25.39$ & 24.46 & 0.65 \\
\hline & \multicolumn{9}{|c|}{ Percentages of head length } \\
\hline Snout length & 30.33 & 13 & $27.83-30.46$ & 29.43 & 0.96 & 15 & $26.96-31.28$ & 29.29 & 1.25 \\
\hline Horizontal eye length & 33.18 & 13 & 29.93-36.00 & 33.00 & 1.82 & 15 & $31.99-37.21$ & 34.56 & 1.57 \\
\hline Postorbital head length & 39.68 & 13 & $37.02-41.66$ & 39.44 & 1.73 & 15 & $37.06-41.46$ & 38.82 & 1.33 \\
\hline Maxillary length & 36.60 & 13 & $33.76-38.07$ & 36.56 & 0.88 & 15 & $35.36-38.75$ & 36.72 & 1.02 \\
\hline Least interorbital width & 34.89 & 13 & $34.58-38.48$ & 35.90 & 1.11 & 15 & $34.97-39.51$ & 36.63 & 1.20 \\
\hline Upper jaw length & 46.98 & 13 & $44.51-48.53$ & 46.12 & 1.09 & 15 & $41.83-49.34$ & 45.64 & 1.47 \\
\hline
\end{tabular}

phylogenetic context describing a new genus, Chrysobrycon, mainly based on secondary sexual characters of males of these two species of Hysteronotus. Therefore the genus Chrysobrycon comprised two species, with $C$. hesperus as the type species by original designation. Chrysobrycon eliasi shares the synapomorphies described in the diagnosis of the genus. However, males of $C$. eliasi have a slightly different pattern of pouch scale, in which such scale completely covers the small additional scale under it, in such a way that the ventral border of the underlying scale is not seen in the lateral view. Chrysobrycon hesperus and C. myersi have an additional medial scale near to, and slightly surpassing, the ventral and posterior border of the pouch scale. Weitzman $e t$ al. (2005) commented that Chrysobrycon species lack the terminal lateral-line tube; however, C. eliasi has the terminal lateral-line tube developed between caudal-fin rays 10-11 (Fig. 5). Mirande (2010) reported the presence of the terminal lateralline tube as synapomophy of the family Characidae.

Chrysobrycon eliasi is the smallest known species of the genus Chrysobrycon. The size of adult males of C. eliasi ranges between 27.58 and $39.90 \mathrm{~mm}$ SL. Weitzman \& Thomerson (1970) reported adult males of $C$. hesperus with SL between 63.40 and $81.80 \mathrm{~mm}$, and adults males of $C$. myersi with SL between 36.50 and $49.60 \mathrm{~mm}$. Males of $C$. hesperus (44.44-78.13 $\mathrm{mm} \mathrm{SL}$ ) and C. myersi (45.46-63.77 mm SL) examined are also larger than those of $C$. eliasi, according to the above-mentioned records; this fact is more evident for both sexes of Chrysobrycon in the PC1 (Figs. 6a-b).

Bushmann et al. (2002: table 2) observed that the gill-gland length measured in one male in each of several species of Xenurobryconini (including Chrysobrycon hesperus) does not surpass $3.00 \%$ of SL; nonetheless, the gill-gland length measured in males of $C$. hesperus in the present study corresponded to $3.16-5.50 \% \mathrm{SL}$, and C. eliasi and C. myersi also exhibited gill glands longer than the known values published for the tribe. Therefore, a comparison using a larger number of males is necessary, because of the scarce information about the gill-gland length, including its intraspecific variation.

The discovery of Chrysobrycon eliasi increases the geographic distribution of the genus to the southeast of the Amazon basin, where the three Chrysobrycon species are allopatric. Chrysobrycon hesperus and C. myersi (Fig. 9) were only known from their type localities (Böhlke, 1958; Weitzman $\&$ Thomerson, 1970). However the examination of paratypes of C. hesperus and C. myersi (ANSP 75914, 79512, and 112325) and the comparative study of Chrysobrycon specimens from different drainages of Ecuador and Peru, with data from original descriptions of both $C$. hesperus and C. myersi, supported the conclusion that $C$. hesperus and $C$. myersi have a larger geographic distribution than that previously known, and that distribution of all Chrysobrycon species should be studied more in detail. 
Comparative material. Chrysobrycon hesperus: Ecuador. ANSP 75914, 1 paratype, $59.49 \mathrm{~mm} \mathrm{SL}$, río Suno near mouth, tributary Upper río Napo, altitude 300-320 m a.s.l. ANSP 79512, 1 paratype, $78.13 \mathrm{~mm}$ SL, río Pucuno, a tributary of río Suno, Upper Napo system, approx. $350 \mathrm{~m}$ a.s.1. Peru. LACM 39937-2, 1, $48.82 \mathrm{~mm}$ SL, Amazonas, Creek Pastazillio (not located), 1.5-1.7 km up from mouth. LACM 41877-1, 1, 46.73 mm SL, Amazonas, Caterpiza Community, río Caterpiza, approx. $3^{\circ} 50^{\prime} \mathrm{S} 77^{\circ} 42^{\prime} \mathrm{W}$. LACM 41930 6, 1, $44.44 \mathrm{~mm}$ SL, Amazonas, $500 \mathrm{~m}$ upstream from Caterpiza approx. $3^{\circ} 50^{\prime} \mathrm{S} 77^{\circ} 42^{\prime} \mathrm{W}$. LACM 42012-5, 5, 43.96-48.69 mm SL, Amazonas, $1 \mathrm{~km}$ downstream from Caterpiza, approx. $3^{\circ} 55^{\prime} \mathrm{S}$ $77^{\circ} 42^{\prime} \mathrm{W}$. MUSM 28665, 3 of $6,36.15-54.58 \mathrm{~mm}$ SL (1 C\&S), Loreto, Alto Amazonas, Andoas, río Corrientes basin, Creek Forestal, 769'25.34”'W 2²1'27.71'S, 237 m a.s.1. Chrysobrycon myersi: Peru. ANSP 112325, 2 paratypes, 36.23-36.55 mm SL, Huanuco, small tributary to río Pachitea, near airstrip at Tournavista. LACM 37720-4, 3, 34.30-63.77 mm SL, Pasco, Iscozacin Valley, Pan de Azúcar, stream about 100 yards above entrance into río Iscozacin. MUSM 38671, 3 of 18, 50.94-60.66 mm SL (1 C\&S), Junín, Satipo, río Tambo basin, Creek Pukakunga, 73²8'2.19”W 11²4'37.27”S, $587 \mathrm{~m}$ a.s.1. Gephyrocharax chaparae: Bolivia. ANSP 68967 , holotype (x-ray), $32.46 \mathrm{~mm} \mathrm{SL}$, Todos Santos, río Chapare. ANSP 68968, 6 of 11 paratypes (4 x-rays), 30.95-44.71 mm SL, collected with the holotype. ANSP 68979,1 paratype, $31.01 \mathrm{~mm} \mathrm{SL}$, mouth of río Chapare, at its junction with río Chimore. ANSP 69195 , holotype of Corynopomops opisthopterus Fowler 1943, $29.76 \mathrm{~mm}$ SL, Todos Santos, río Chapare. Gephyrocharax major: Bolivia. CAS 44286, 9 syntypes (9 x-rays), 35.87-56.44 mm SL, Beni, río Popoi, upper río Beni basin.

\section{Acknowledgements}

We thank the members of the ichthyology lab at MUSM by their help and collaboration, especially to V. Meza-Vargas, J. Chuctaya, and M. Hidalgo; Earthwatch Institute and Andean Amazon Rivers Program (2004); Mariangeles Arce (MCP) provided photos of some material deposited at ANSP; John Lundberg, Mark Sabaj and Kyle Luckenbill (ANSP), Rick Feeny (LACM), Jon Fong, and Dave Catania (CAS) for sending material, images or X-rays; Bruno Pianzola for the photographs of the type and paratype, and two anonymous reviewers for the corrections that improved the manuscript. We are grateful to D. Phillip for English corrections and suggestions. This study benefited with a Latin-American grant CONICET-Argentina and financial support by the Project 2814 (JAV-R.), Fundación para Promoción de la Investigación y la Tecnología, Banco de la Republica, Colombia. For financial support CONICET and ANPCYT (PICT 913, MMA.).

\section{Literature Cited}

Böhlke, J. 1958. Studies on Fishes of the family Characidae. $N^{\circ} 14$. A report on several extensive recent collections from Ecuador. Proceedings of the Academy of Natural Sciences of Philadelphia, 110: 1-121.

Burns, J. R., S. H. Weitzman, H. J. Grier \& N. A. Menezes. 1995. Internal fertilization, testis and sperm morphology in glandulocaudine fishes (Teleostei: Characidae: Glandulocaudinae). Journal of Morphology, 224: 131-145.
Bushmann, P. J., J. R. Burns \& S. H. Weitzman. 2002. Gill-derived glands in glandulocaudine fishes (Teleostei: Characidae: Glandulocaudinae). Journal of Morphology, 253: 187-195.

Castro, R. M. C., A. C. Ribeiro, R. C. Benine \& A. L. A. Melo. 2003. Lophiobrycon weitzmani, a new genus and species of glandulocaudine fish (Characiformes: Characidae) from the rio Grande drainage, upper rio Paraná system, southeastern Brazil. Neotropical Ichthyology, 1: 11-19.

Eschmeyer, W. 1998. Catalog of fishes. Volume 1. California Academy of Natural Sciences, KNI Incorporated, Anaheim, California, 958p.

Fink, W. L. \& S. H. Weitzman. 1974. The so-called cheirodontin fishes of central America with descriptions of two new species (Pisces: Characidae). Smithsonian Contributions to Zoology, 172: $1-46$

Hammer, Ø., D. A. T. Harper \& P. D. Ryan. 2001. PAST: Paleontological Statistics Software Package for Education and Data Analysis. Palaeontologia Electronica, 4: 1-9. Electronically accessible at http://palaeo-electronica.org/2001_1/past/ issue 1_01.htm

Marcus, L. F. 1988. Traditional morphometrics. Pp. 77-122. In: Rohlf, F. J. \& F. L. Bookstein (Eds.). Proceeding of the Michigan Morphometrics Workshop. Special Publication 2, Michigan, Museum of Zoology, University of Michigan, 380p.

Menezes, N. A. \& S. H. Weitzman. 2009. Systematics of the Neotropical fish subfamily Glandulocaudinae (Teleostei: Characiformes: Characidae). Neotropical Ichthyology, 7: 295-370.

Mirande, J. M. 2009. Weighted parsimony phylogeny of the family Characidae (Teleostei: Characiformes). Cladistics, 25: 574-613.

Mirande, J. M. 2010. Phylogeny of the family Characidae (Teleostei: Characiformes): from characters to taxonomy. Neotropical Ichthyology, 8: 385-568.

Taylor, W. R. \& G. C. van Dyke. 1985. Revised procedures for staining and clearing small fishes and other vertebrates for bone and cartilage study. Cybium, 9: 107-119.

Weitzman, S. H. 2003. Subfamily Glandulocaudinae (Characins, tetras). Pp. 222-230. In: Reis, R. E., S. O. Kullander \& C. J. Ferraris Jr. (Eds.). Check List of the Freshwater Fishes of South and Central America. Porto Alegre, Edipucrs, 729p.

Weitzman, S. H. \& J. E. Thomerson. 1970. A new species of glandulocaudine characid fish, Hysteronotus myersi, from Peru. Proceedings of the California Academy of Sciences, 38: 139-156.

Weitzman, S. H. \& N. A. Menezes. 1998. Relationships of the tribes and genera of the Glandulocaudinae (Ostariophysi: Characiformes: Characidae) with a description of a new genus, Chrysobrycon. Pp. 171-192. In: Malabarba, L. R., R. E. Reis, R. P. Vari, Z. M. S. Lucena \& C. A. S. Lucena (Eds.). Phylogeny and Classification of Neotropical Fishes. Porto Alegre, Edipucrs, 603p.

Weitzman, S. H., N. A. Menezes, J. R. Burns \& H-Georg Evers. 2005. Putative relationships among inseminating and externally fertilizing characids, with a description of a new genus and species of Brazilian inseminating fish bearing an anal-fin gland in males (Characiformes: Characidae). Neotropical Ichthyology, 3: 329-360.

Submitted May 30, 2011 Accepted October 24, 2011 Published December 26, 2011 